\title{
Giuditta Giardini*
}

gg2721@columbia.edu

orcid.org/0000-0003-1686-6557

Università degli Studi di Ferrara

Via Ludovico Ariosto, 35

44121, Ferrara, Italy

\section{A Commentary to Commission Implementing Regulation (EU) 2021/1079 of 24 June 2021 Laying Down Detailed Rules for Implementing Certain Provisions of Regulation (EU) 2019/880 of the European Parliament and of the Council on the Introduction and the Import of Cultural Goods}

\begin{abstract}
Regulation (EU) 2019/880 of the European Parliament and of the Council assigned implementing powers to the European Commission to adopt uniform provisions for effectively enforcing new rules on the import of cultural goods. The present commentary navigates the text of the Commission Implementing Regulation (EU) 2021/1079 of 24 June 2021 ("Implementing Regulation"), adopted to ensure the uniform implementation of the said import legislation by the Member States. The text of the Committee's instrument sets up exemptions from the documentation requirements for certain cat-
\end{abstract}

\footnotetext{
* Giuditta Giardini is a lawyer serving as a consultant for the Antiquities Trafficking Unit at the Manhattan District Attorney's Office, New York (USA). She holds an LL.M. from Columbia Law School. Before moving to New York, she worked for UNIDROIT focusing on the 1995 UNIDROIT Convention on Stolen or Illegally Exported Cultural Objects. She writes for the ArtEconomy24 page of the Italian financial newspaper II Sole24Ore. She is a member of the International Council of Museums (ICOM) and European Law Institute (ELI).
} 


\section{LEGAL COMMENTARIES}

Giuditta Giardini

egories of goods; contains detailed provisions on import licenses and statements; and establishes rules for the electronic system for the import of cultural goods. The ambitious provisions of the Implementing Regulation raise some important questions, e.g. whether the electronic system will facilitate the work of custom agents or engulf it; or whether national export offices and legislative bodies will step up to the challenge and quickly adapt to the new system and new rules.

Keywords: import of cultural goods, provenance, European Regulation, electronic system, import license, import statement

\section{Introduction and Legal Basis}

\section{The Single Market challenge}

One of the core objectives of the European Economic Community (EEC) was the creation of a common market offering the free movement of goods, services, people, and capital (the so-called "four freedoms"). The adoption of the Single European Act ${ }^{1}$ marked a crucial step towards the development of the Single European Market, which was launched on 1 January 1993. The single market sought to guarantee the "four freedoms"; and the free movement of goods was secured through the elimination of customs duties, quantitative restrictions and the prohibition of measures having an equivalent effect. However, Article 36 of the Treaty on the Functioning of the European Union ${ }^{2}$ allows Member States to take measures to protect national interests in the form of goods when such protection was justified by general, non-economic considerations (e.g. public morality, public policy, or public security). Article 36 also ensures the safeguarding of national treasures possessing artistic, historic, or archaeological value. On 9 December 1992, one month before the opening of the Single Market, the Council adopted Regulation (EEC) No. 3911/92 on the export of cultural goods. ${ }^{3}$ This Regulation set up a European export licensing system for art objects, defined in the Annex to the text. Several months later, on 15 March 1993, the Council adopted Directive 93/7/EEC

1 OJ L 169, 29.06.1987, p. 1.

2 Consolidated version of the Treaty on the Functioning of the European Union, OJ C 115, 9.05.2008, p. 47. The consolidated version is the result of the amendments introduced by the Treaty of Lisbon, OJ C 306 , 17.12.2007, p. 1. 
on the return of cultural objects unlawfully removed from the territory of a Member State, ${ }^{4}$ which established international rules for the restitution of cultural objects illegally exported from Member States of the European Union (EU) in breach of regional and national export laws. Until 2019, the EU only regulated the cultural property flows unilaterally. While the rules in place prevented cultural property originating from Member States to be dispersed, nothing shielded third countries' illegally exported cultural property from crossing the EU boundaries and freely circulating internally. Therefore, the only rules in place to control the flows of illegally-exported cultural property from third countries were temporary restrictions concerning cultural property from conflict zones. ${ }^{5}$ Only after the United Nations Security Council's Resolution 2199/2015 acknowledged the link existing between the illicit trafficking of cultural objects and terrorist financing, ${ }^{6}$ did the threat posed by terrorist groups in the near Middle East trigger the reaction of European lawmakers. The following years, the Council Conclusions of 12 February 2016 on the fight against the financing of terrorism, ${ }^{7}$ the Communication from the Commission to the European Parliament and the Council of 2 February 2016 on an Action Plan for strengthening the fight against terrorist financing, ${ }^{8}$ and Directive (EU) 2017/541 of the European Parliament and of the Council ${ }^{9}$ were adopted and became common rules in place on trade with third countries. These rules formed the legal basis for the new regulations discussed in this article, which sets out the conditions for the import of cultural property originating from third countries having regard to the fight against the illicit trade in cultural goods, in particular where such trade could contribute to terrorist financing.

\footnotetext{
4 OJ L 74, 27.03.1993, p. 74. It was clarified and extended by Directive 2014/60/EU of the European Parliament and of the Council of 15 May 2014 on the return of cultural objects unlawfully removed from the territory of a Member State and amending Regulation (EU) No. 1024/2012 (Recast), OJ L 159, 28.05.2014, p. 1.

5 On 7 July 2003, as a result of the Council Regulation (EC) No. 1210/2003 of 7 July 2003 concerning certain specific restrictions on economic and financial relations with Iraq and repealing Regulation (EC) No. 2465/96, OJ L 169, 8.07.2003, p. 6, the EU applied specific restrictions to trade in goods belonging to Iraq's cultural heritage, with the objective of facilitating the safe return of those goods. Eight years later, on 9 May 2011, in Council Regulation (EU) No. 442/2011 of 9 May 2011 concerning restrictive measures in view of the situation in Syria, OJ L 121, 10.05.2011, p. 1, the same restrictions were applied to Syrian cultural heritage.

612 February 2015, S/RES/2199 (2015).

7 https://data.consilium.europa.eu/doc/document/ST-6068-2016-INIT/en/pdf [accessed: 17.12.2021].

$8 \operatorname{COM}(2016) 50$ final.

9 Directive (EU) 2017/541 of the European Parliament and of the Council of 15 March 2017 on combating terrorism and replacing Council Framework Decision 2002/475/JHA and amending Council Decision 2005/671/JHA, OJ L 88, 31.03.2017, p. 6.
} 


\section{LEGAL COMMENTARIES}

Giuditta Giardini

Regulation (EU) 2019/880

Similarly to Regulation 116/2009, Regulation (EU) 2019/880 on the introduction and the import of cultural goods ${ }^{10}$ provides for a system of import licences for third countries' cultural property in danger or most likely to be looted in their countries of origin, and importer statements for other categories of cultural goods not at risk. Pursuant to Article 4, any applicant who wishes to import into the EU territory any of the high-risk objects referred to in Part B of the Annex (i.e. products of archaeological excavations, or discovery on land or underwater, or parts of monuments at least 250 years old) needs an import license regardless of the value of the object. In order to import these high-risk objects, the importer must apply for an import license to the competent authority in the Member State, using a new electronic system set up under Article 8 and not yet operational. The application must be accompanied by any supporting documents and information providing evidence that the cultural good in question has been exported from the country where it was created or discovered in accordance with the laws and regulations of that country, or providing evidence of the absence of such laws and regulations at the time when the object was exported. Based on Article 5, for lower-risk objects listed in Part C of the Annex - such as zoological or botanical collections, coins, ethnographic objects, paintings, sculptures, manuscripts, and books that are more than 200 years old and have a value above $€ 18,000$ - an importer statement must be submitted to the customs authorities. Such a statement consists of a declaration that the cultural good in question has been lawfully exported from a non-EU country, accompanied by a standardized description of the object. Article 2(1)(4) exempts "returned goods", defined as such by Article 203 of Regulation (EU) No. 952/2013, ${ }^{11}$ from the new licensing regime. While the Regulation underwent numerous amendments during the legislative process, art collectors and dealers still feel uneasy about these additional compliance burdens.

Commission Implementing Regulation (EU) 2021/1079 of 24 June 2021

\section{Legal basis and preparatory work}

Recital (22) of Regulation (EU) 2019/880 assigned implementing powers to the Commission to: adopt uniform conditions regarding the temporary admission of cultural goods and their custody; to draft templates for import license applications

\footnotetext{
10 OJ L 151, 7.06.2019, p. 1.
}

11 Article 203 of the Regulation (EU) No. 952/2013 laying down the Union Customs Code, OJ C 229, 31.07 .2012 , p. 68, defines returned goods as "non-Union goods which, having originally been exported as Union goods from the customs territory of the Union, are returned to that territory within a period of three years and declared for release for free circulation". 
and forms; and to establish an electronic system for the submission of applications and statements, the storage of documentation, and the exchange of information between Member States. Therefore, immediately after the adoption of Regulation (EU) 2019/880, the European Commission Directorate-General for Taxation and Customs Union (DG TAXUD) and the Committee on the Export of Cultural Goods began working on the Implementing Regulation. On 24 March 2021, the Commission circulated a draft text among relevant stakeholders, ${ }^{12}$ and any interested party had four weeks to send comments back. Major stakeholders, such as UNESCO, UNIDROIT, WCO, INTERPOL, and ICOM, contributed to the revision of the draft. The final text, adopted on 24 June 2021, is broken down into four sections. Chapter II sets up detailed exemptions from the documentary requirements for certain goods; Chapters III and IV focus on import licenses and on importer statements, respectively; and Chapter $\mathrm{V}$ regulates the new electronic system. ${ }^{13}$

\section{Detailed arrangements for an exemption from documentary requirements}

Chapter II of the Implementing Regulation details three types of temporary admissions of protected cultural property which may be imported without an import license or an importer statement. Return goods (Article 3(4)(a) of Regulation (EU) 2019/880); cultural goods at risk (Article 3(4)(b)); and cultural goods imported for scientific and educational purposes, or to be offered for sale in international art fairs (Article 3(4)(c)), are not subject to documentary requirements. ${ }^{14}$ The rationale behind Article 3(4)(b) is that even cultural property that falls within the protected categories ${ }^{15}$ can cross European borders if their integrity and conservation is at stake. This provision ensures the maintenance of safe havens in European territories. Cultural property will be temporarily preserved in refuges and storage facilities, different from freeports, built in Member States and placed under the control of a designated public authority inscribed with the electronic system for the import of cultural goods ("ICG"). ${ }^{16}$ The import of goods at risk re-

\footnotetext{
12 The draft text is available at: https://eur-lex.europa.eu/legal-content/EN/TXT/?uri=pi_com\%3AAres \%282021\%292087089 [accessed: 31.10.2021].

13 Commission Implementing Regulation (EU) 2021/1079 of 24 June 2021 laying down detailed rules for implementing certain provisions of Regulation (EU) 2019/880 of the European Parliament and of the Council on the introduction and the import of cultural goods, OJ L 234, 2.07.2021, p. 67.

14 Based on Article 4(1), the person who wishes to import into the territory of the EU a cultural good exempted from the documentary requirements laid down in Article 3(4) points (b) and (c) of Regulation (EU) $2019 / 880$ has to file only a standardized general description of the goods in the ICG system before lodging the corresponding customs declaration. Annex I to the Implementing Regulation contains the data dictionary to complete the standardized general description. Ibidem.

15 The categories are those listed under Parts B and C of the Annex. Regulation (EU) 2019/880, Article 2(4).

16 Implementing Regulation, Article 2(2).
} 


\section{LEGAL COMMENTARIES}

Giuditta Giardini

quires the prior acceptance of an official request for safekeeping, submitted by a public authority of the third country processing or holding the cultural goods to the designated public authority in the EU. ${ }^{17}$ The content of the Regulation exceeds the provisions of The Hague Convention of 1954 and its First Protocol ${ }^{18}$ by allowing - during permanent stays in refuges - the display of cultural objects upon the prior approval of both the country from where the objects come from and the competent EU customs authority.

\section{The import license}

The applicant seeking an import license is fully responsible for any mendacious statement made when filing an application for an import license for objects listed in Article 4 of Regulation (EU) 2019/880. ${ }^{19}$ The applicant ${ }^{20}$ bears the burden of proving that the art goods he or she wishes to import have been exported from the country of interest in accordance with its patrimony laws; or alternatively has to "provide evidence of the absence of such laws and regulations at the time the cultural good was taken out of its territory". ${ }^{21}$ Article 8(1)(c) and (d) contains a detailed list of documents to submit when filing an application. The list includes, but it is not limited to, a colour photograph of the object; previous customs documentation providing evidence of past movements of the object; sale and shipping invoices; insurance papers; appraisal publications, including auction catalogues, condition reports, and any title, deed, will, or document from which the ownership of the property can be determined.

\section{The importer statement}

For categories of cultural goods the import of which does not require an import license, the importer is responsible for their lawful export from third countries and should provide sufficient information for the identification of the object by the customs authorities. The level of care required from the importer is an undefined "due diligence". ${ }^{22}$ In order to facilitate the procedure and to ensure legal certainty, the importer must file, together with the import statement, a standardized document provided for in Annex II of the Implementing Regulation. The template adopts

\footnotetext{
17 Ibidem, Article 5. Yet based on Article 2(6), if no prior request has been made and no agreement is reached the Member State hosting the refuge bears the storage and maintenance costs.

18 Convention for the Protection of Cultural Property in the Event of Armed Conflict, 14 May 1954, 249 UNTS 240.

19 The applicant signs a declaration taking responsibility for the veracity of all statements made in the application. Implementing Regulation, Article 8(1)(a).

20 Both applicants for an import license or submitters of an importer statement are identified through an EORI number. The EORI number is the Economic Operators Registration and Identification number for businesses which undertake the import or export of goods into or out of the EU.

21 Implementing Regulation, Article 8(1).

22 Ibidem, Article 12(1).
} 
the ICOM-Getty Institute Object ID standard criteria to facilitate the identification of art objects by customs authorities and ensure traceability after the cultural goods enter the internal market. The form allows for risk analysis and targeted controls. Upon request of the competent customs authority, the importer must file any of the documents listed under Article 12(4)(a)-(k) that are mandatory for an import license application according to Article 8(1)(d)(i)-(xi), including the law of the country of interest when it subjects the export of cultural goods from its territory to the obtainment of a prior authorization.

The electronic system for the import of cultural goods (ICG)

The effectiveness of Regulation (EU) 2019/880 revolves around the efficacy of the ICG system. ${ }^{23}$ The centralized electronic system is to become operational within a period of six years from the entry into force of the Regulation. ${ }^{24}$ The Commission is necessarily responsible for the setting up, functioning, and periodical updating of the system, ${ }^{25}$ while Member States through their contact points will monitor the overall process. ${ }^{26}$ Both applications for import licenses (Article 17) and importer statements (Article 18), electronically signed by applicants and submitters, have to be filed via the ICG system. Further formalities will be carried out electronically on both sides, ${ }^{27}$ including any request by the competent authority for missing or additional information. The novelty of the ICG system lies in its hybrid nature, which allows it to exchange and simultaneously store information on art goods placed on the EU market, even temporarily. The electronic system will maintain important data regarding flows of cultural goods inside the EU boundaries, which will complement existing data on exported goods. At the same time, the system will guarantee the confidentiality of the carriers' information (Article 20). Applicants and submitters maintain access to their own individual positions on the ICG system to review their import licenses, importer statements, and general descriptions of the objects. In order to ensure consistency with previous assessments and to facilitate trade, any new application for the re-importation of the same cultural good will be subject to simplified requirements and will maintain the documentation already uploaded (Article 7).

\footnotetext{
23 Implementing Regulation, Recital 16.

24 Part of the project on the import of cultural goods is developed also within the EU Single Window Environment for Customs, designed to provide quicker and more efficient sharing of electronic data between different government authorities involved in goods clearance at the border. European Commission, Report from the Commission to the European Parliament and the Council pursuant to Article 14(3) of Regulation (EU) 2019/880 of the European Parliament and of the Council of 17 April 2019 on the introduction and the import of cultural goods, 30 July 2020, COM(2020) 342 final.

25 Implementing Regulation, Article 14.

26 Ibidem, Article 15.

27 Ibidem, Article 17(3)(a)-(e).
} 


\section{LEGAL COMMENTARIES}

Giuditta Giardini

\section{Conclusions}

The present Commentary has emphasized the crucial role of the electronic system for the safe importation of cultural goods. To the extent that it will be fully employed by all European customs agencies by 28 June 2025 at the latest, the ICG system should prove fundamental to protect the European art market. Despite the criticism that followed the adoption of Regulation (EU) 2019/880 as being another item in the EU emotional agenda riding the wave of terror generated by the Islamic State's attacks on sites and museums, the creation of an electronic system was an overdue change. More problematic however are the practical aspects of the implementing legislation. With national export offices still unable to control the exit of all cultural property from Member States, and occasionally engulfed by incoming applications, controlling the illegal import of third country's goods places a heavier burden and increased liabilities on European authorities. The pressure is all on customs agents. In accordance with Article 4(6) of Regulation (EU) 2019/880, the competent authority has 21 days to make requests for additional information. Once the applicant has submitted the requested information (within 40 days), the competent authority will examine it and make a decision within 90 days. ${ }^{28}$ In their haste to make quick determinations so as not to clog the access doors to the European market, customs agents will have to promptly decide whether or not to subject the applicants to in-person checks of the object or to request more documentation. Everything hinges on the efficiency and speed of the ICG system, which must guarantee rapid and efficient communication between the various authorities located throughout the Member States in order to prevent system delays from nullifying legislative efforts. On the other hand, art collectors and dealers bear the responsibility of carefully researching the provenance of the objects they intend to import into the EU and request the appropriate import and export licenses to meet the criteria of the Implementing Regulation. Since the new system imposes the electronic filing of laws in place in the country of origin or in the State where the object has been located for five years, dealers and collectors may have to seek legal advice from experts in the country where the object comes from.

28 Ibidem, Article 9. 


\section{References}

Commission Implementing Regulation (EU) 2021/1079 of 24 June 2021 laying down detailed rules for implementing certain provisions of Regulation (EU) 2019/880 of the European Parliament and of the Council on the introduction and the import of cultural goods, OJ L 234, 2.07.2021, p. 67.

Consolidated version of the Treaty on the Functioning of the European Union, OJ C 115, 9.05.2008, p. 47.

Convention for the Protection of Cultural Property in the Event of Armed Conflict, 14 May 1954, 249 UNTS 240.

Council Directive 93/7/EEC of 15 March 1993 on the return of cultural objects unlawfully removed from the territory of a Member State, OJ L 74, 27.03.1993, p. 74.

Council of the European Union, Council Conclusions on the Fight Against the Financing of Terrorism, 12 February 2016, https://data.consilium.europa.eu/doc/document/ST-60682016-INIT/en/pdf [accessed: 17.12.2021].

Council Regulation (EC) No. 116/2009 of 18 December 2008 on the export of cultural goods (Codified version), OJ L 39, 10.02.2009, p. 1.

Council Regulation (EC) No. 1210/2003 of 7 July 2003 concerning certain specific restrictions on economic and financial relations with Iraq and repealing Regulation (EC) No. 2465/96, OJ L 169, 8.07.2003, p. 6.

Council Regulation (EEC) No. 3911/92 of 9 December 1992 on the export of cultural goods, OJ L 395, 31.12.1992, p. 1.

Council Regulation (EU) No. 442/2011 of 9 May 2011 concerning restrictive measures in view of the situation in Syria, OJ L 121, 10.05.2011, p. 1.

Directive (EU) 2017/541 of the European Parliament and of the Council of 15 March 2017 on combating terrorism and replacing Council Framework Decision 2002/475/JHA and amending Council Decision 2005/671/JHA, OJ L 88, 31.03.2017, p. 6.

Directive 2014/60/EU of the European Parliament and of the Council of 15 May 2014 on the return of cultural objects unlawfully removed from the territory of a Member State and amending Regulation (EU) No. 1024/2012 (Recast), OJ L 159, 28.05.2014, p. 1.

European Commission, Communication from the Commission to the European Parliament and the Council on an Action Plan for Strengthening the Fight Against Terrorist Financing, 2 February 2016, $\operatorname{COM}(2016) 50$ final.

European Commission, Report from the Commission to the European Parliament and the Council pursuant to Article 14(3) of Regulation (EU) 2019/880 of the European Parliament and of the Council of 17 April 2019 on the introduction and the import of cultural goods, 30 July 2020, $\operatorname{COM(2020)~} 342$ final.

Regulation (EU) 2019/880 of the European Parliament and of the Council of 17 April 2019 on the introduction and the import of cultural goods, OJ L 151, 7.06.2019, p. 1.

Regulation (EU) No. 952/2013 laying down the Union Customs Code, OJ C 229, 31.07.2012, p. 68.

Single European Act, OJ L 169, 29.06.1987, p. 1. 


\section{LEGAL COMMENTARIES}

Giuditta Giardini

Treaty of Lisbon amending the Treaty on European Union and the Treaty establishing the European Community, signed at Lisbon, 13 December 2007, OJ C 306, 17.12.2007, p. 1.

United Nations Security Council, Resolution 2199: Threats to International Peace and Security Caused by Terrorist Acts, 12 February 2015, S/RES/2199 (2015). 